\title{
Evaluation of eggplant and gilo genotypes and interspecific hybrids as to root-knot nematode resistance
}

Jadir Borges Pinheiro ${ }^{1}$, Giovani Olegario da Silva ${ }^{1}$, Jhenef Gomes de Jesus ${ }^{2}$, Danielle Biscaia ${ }^{1}$, Raphael Augusto de Castro e Melo ${ }^{1}$

${ }^{1}$ Empresa Brasileira de Pesquisa Agropecuária - EMBRAPA. ${ }^{2}$ Centro Universitário ICESP, Brasília, DF. E-mail: jadir.pinheiro@embrapa.br

\section{Resumo}

No Brasil, as culturas da berinjela e do jiló são importantes para a economia de pequenas propriedades localizadas principalmente nos estados do Sudeste, bem como de outras regiões, com expressivo volume de produção o ano todo nos mercados atacadistas locais. No entanto, essas espécies são muito suscetíveis aos nematoides das galhas e há poucas ou quase nenhuma fonte conhecida de resistência. Desta forma, o objetivo do presente estudo foi buscar fontes de resistência aos nematoides das galhas em genótipos de berinjela e jiló; bem como em híbridos interespecíficos para uso como porta-enxertos. Foram realizados três experimentos: no primeiro, realizado em 2013, foram avaliados 10 acessos experimentais de berinjela, um híbrido entre berinjela e jiló, e um híbrido de Solanum stramonifolium com berinjela para a reação ao Meloidogyne enterolobii. No segundo, em 2016, foram avaliados 20 acessos experimentais de jiló, para a reação ao $M$. incognita, $M$. javanica e $M$. enterolobii. E no terceiro, em 2017, foram avaliados um acesso e dois híbridos experimentais de berinjela, e um híbrido de Solanum scuticum com berinjela, para a reação ao M. incognita, e M. enterolobii. Ambos ensaios foram conduzidos em casa de vegetação, e caracteres relacionados à infeção das raízes pelos nematoides foram avaliados em delineamento inteiramente casualizado, com seis repetições, sendo a unidade experimental uma planta cultivada em um vaso contendo 1,5 L de substrato inoculado com cada espécie de nematoide. Foi verificado que: 1- todos os acessos avaliados de berinjela foram suscetíveis ao $M$. incognita e ao $M$. enterolobii, no entanto, o acesso BER 3150 apresentou menor grau de suscetibilidade ao $M$. incognita. 2- os genótipos de jiló CNPH 056, CNPH 070, CNPH 220 e CNPH 363 apresentaram melhor resposta a M. incognita e M. javanica do que o padrão de suscetibilidade, o tomateiro 'Rutgers'. 3- os acessos de jiló CNPH 070, CNPH 219 e CNPH 387, apresentaram resposta melhor ou equivalente ao tomateiro resistente 'Nemadoro' para M. enterolobii. 4- o híbrido interespecífico BER EG203 x S. scuticum, pode ser recomendado como porta-enxerto para materiais de berinjela muito suscetíveis ao $M$. incognita; bem como a solanacea silvestre $S$. stramonifolium var. inerme para o M. enterolobii.

Palavras-chave: M. enterolobii; M. incognita; M. javanica; Solanum aethiopicum gr. Gilo; Solanum melongena $\mathrm{L}$.

Avaliação de genótipos de berinjela e jiló e híbridos interespecíficos quanto a resistência a nematoides das galhas

\begin{abstract}
In Brazil, eggplant and gilo are important for the economy of small-scale farms located mainly in the southeast states and other regions, with a significant production volume year-round in the wholesale local markets. However, these species are very susceptible to root-knot nematodes, and there are few or almost none known sources of resistance. The objective of this study was to prospect sources of resistance to rootknot nematodes in eggplant, scarlet eggplant (gilo), as well in interspecific hybrids between these species and with wild Solanum species, to be used as rootstocks. In the first experiment, in 2013, 10 eggplant accessions, a hybrid between eggplant and gilo, and a Solanum stramonifolium $x$ eggplant hybrid, were evalu41ated for their reaction to Meloidogyne enterolobii. In the second, in 2016, 20 accessions of gilo
\end{abstract}


were evaluated for their reaction to $M$. incognita, $M$. javanica, and $M$. enterolobii.. And in the third experiment, in 2017, one access and two experimental eggplant hybrids, and one Solanum scuticum $\mathrm{x}$ eggplant hybrid, were evaluated for their reaction to $M$. incognita, and $M$. enterolobii. All the trials were stablished in a greenhouse, and characters related to root infection were evaluated in a completely randomized design with six replications of one plant per pot, using a $1.5 \mathrm{~L}$ pots filled with a mixed substrate inoculated with each nematode species. It was found that all eggplant accessions were susceptible to $M$. incognita and $M$. enterolobii, however, BER 3150 presented lower susceptibility to $M$. incognita. The gilo genotypes CNPH 056, CNPH 070, CNPH 220, and CNPH 363 shown better response to $M$. incognita and $M$. javanica than the susceptibility pattern, the tomato 'Rutgers'. Other gilo accessions CNPH 070, CNPH 219, and $\mathrm{CNPH} 387$ showed better or equivalent response than the resistant tomato 'Nemadoro' for $M$. enterolobii. 4- the BER EG203 x S. scuticum interspecific hybrid can be recommended as a rootstock for eggplant susceptible to $M$. incognita, as well the wild $S$. stramonifolium var. inerme species for $M$. enterolobii.

Keywords: M. enterolobii; M. incognita; M. javanica; Solanum aethiopicum gr. gilo.; Solanum melongena L.

\section{Introduction}

The genus Meloidogyne is considered the most important among plant-parasitic nematodes worldwide, presenting a wide geographical distribution and a huge range of hosts, being responsible for economic damage in several crops (NTALLI et al., 2016; BERNARD et al., 2017). These nematodes are responsible for one of the main constraints of the eggplant (Solanum melongena L.) production, as well for scarlet eggplant (Solanum aethiopicum gr. gilo), with occurrences mostly attributed to Meloidogyne incognita, $M$. javanica, $M$. enterolobii and $M$. hapla (PINHEIRO et al., 2013, OZARSLANDAN et al., 2019, RAMADAN; SOLIMAN, 2020).

In Brazil, these two vegetables are important for the economy of small-scale farms located mainly in the southeast states (Rio de Janeiro, São Paulo, and Minas Gerais) and other regions, with a significant production volume year-round in the wholesale local markets (PINHEIRO et al., 2015). As a case in point, scarlet eggplant surpasses eggplant volumes commercialized in the Ceasa-MG Belo Horizonte market, with an annual quantity of around $12 \mathrm{Kt}$ (MONTEIRO, 2009). Its popularity is confirmed by the recent interest amongst American growers that cultivate this unfamiliar species to attend the demand for ethnic vegetables by the large population of Brazilian immigrants that live in Massachusetts, New Jersey, and New York (MANGAN et al., 2008).

The aforementioned nematodes, additionally to the presence of galls on the roots, present other symptoms that are observed in the plants' canopy, for example, dwarfism, wilt, chlorosis, nutritional deficiencies, and reduced fruit size, consequently leading to low yields (PINHEIRO et al., 2013).

Studies confirm the high susceptibility of these species to root-knot nematodes, since most of the evaluated accessions are classified as susceptible, although there are differences in the degrees of their susceptibility (ULLAH et al., 2011; SHAKEEL et al., 2012; BEGUM et al., 2014; ABDULSALAM et al., 2018). For eggplant, only a few studies demonstrate the existence of resistant genotypes (BOITEUX; CHARCHAR, 1996; TANIMOLA et al., 2015, COLAK-ATES et al., 2018).

Due to the scarcity of resistant genotypes, the use of grafting has potential, since there is the possibility of using other species of the Solanaceae family as rootstocks to control soilborne diseases (GOTO et al., 2003; COHEN et al., 2017). Mendonça et al. (2017) state that some factors may interfere with the viability of this technique, such as obtaining seedlings with similar stem diameters, synchrony of the grafts and rootstocks development; and difficulties related to the presence of thorns in wild rootstocks species. These authors recommend the technique of interspecific crosses between these resistant Solanaceous with a inermis parental, aiming at obtaining rootstocks with fewer thorns and greater compatibility, maintaining their resistance.

The objective of this study was to prospect sources of resistance to root-knot nematodes in eggplant, scarlet eggplant (gilo), as well in interspecific hybrids between these species and with wild Solanum species, to be used as rootstocks. 


\section{Material and Methods}

The experiments were carried out in 2013, 2016, and 2017 in Brasília-DF, Brazil - Centro Nacional de Pesquisa de Hortaliças - CNPH (S15 ${ }^{\circ}$ $56^{\prime}, \mathrm{W} 48^{\circ} 08^{\prime}, 996$ masl) in a plastic greenhouse with $6.5 \mathrm{~m}$ of width, $18.5 \mathrm{~m}$ of length, and $4.5 \mathrm{~m}$ of ceiling height. In 2013, 10 accessions of eggplant (Solanum melongena L.), a hybrid between eggplant and scarlet eggplant, and a hybrid of Solanum stramonifolium with the eggplant cultivar 'Ciça', obtained in 2012, were evaluated for the reaction to M. enterolobii. In 2017 one access (BER 3150) and two experimental eggplant hybrids (BER $171 \times$ BER EG203 and BER 778 x BER EG203), and one hybrid of Solanum scuticum with eggplant BER EG203 obtained in 2016, were evaluated for the reaction to $M$. incognita, and $M$. enterolobii. And in 2016, 20 experimental accessions of scarlet eggplant were evaluated for the reaction to $M$. incognita, $M$. javanica, and $M$. enterolobii. All accessions belonging to Embrapa Hortaliças germplasm bank. The tomato cultivar Rutgers was used as a susceptibility standard (PINHEIRO et al., 2009; PINHEIRO et al., 2020) and as a resistance standard the tomato 'Nemadoro' (PINHEIRO et al., 2009; PINHEIRO et al., 2020) in 2013 and 2016, and one accession of $S$. stramonifolium var. inerme (PINHEIRO et al., 2009; PINHEIRO et al., 2020) in 2017.

The experiments were conducted in a completely randomized design with six replications, and the experimental unit was represented by a single plant per pot. The sowing was carried out in styrofoam trays, on July 3, 2013, October 23, 2016 and May 15, 2017; and about 30 days later, transplantations were carried out into $1.5 \mathrm{~L}$ plastic pots containing a mixed substrate composed of sterilized soil, sterilized sand, highheat composted cattle manure and burnt rice straw, in the proportion of 1:1:1:1. The mixed substrate fertilization was carried out with $300 \mathrm{~g}$ of the formulation NPK 4-30-16 and $300 \mathrm{~g}$ of dolomitic limestone per $300 \mathrm{~kg}$ of substrate. After transplanting, seedling roots were inoculated with 4,000 eggs and eventual second-stage juveniles (J2), of the respective nematode species, in $5 \mathrm{ml}$ of water distributed around the plants.

Seventy days after inoculation in 2013, and 60 days for 2014 and 2017, the following factors were determined: Egg mass index (EMI) the root systems were washed in flowing water and then colored by immersion in a Phloxin B solution in the proportion of 0.5 grams per $L$ of water for 15 minutes. Then, the nematode egg mass number was counted under a stereomicroscope, in the entire root system of each plant/replication (DICKSON; STRUBLE, 1965). The root EMI was obtained according to Taylor and Sasser (1978) using a scale of grades ranging from 0 to 5 , where: $0=$ roots without egg masses; 1 = presence of 1 to 2 egg masses; 2 = presence of 3 to 10 egg masses; $3=$ presence of 11 to 30 egg masses; $4=$ presence of 31 to 100 egg masses and $5=$ presence of more than 100 egg masses. For the 2013 and 2017 experiments, the gall index (GI) was also evaluated, as the number of galls in the root system of each plant/replication. The $\mathrm{Gl}$ in the roots was represented by the scale from 0 to 5 , according to Taylor and Sasser (1978), replacing the quantification of egg masses by galls, to then make the attribution of grades. In addition to the reproduction factor (RF) - obtained by dividing the final and initial population densities of the nematodes $(\mathrm{RF}=\mathrm{Pf} / \mathrm{Pi})$. The initial population (Pi) was considered to be the inoculated population, and the final population (Pf) was quantified by extracting the root systems according to the technique of Boneti and Ferraz (1981). Plants with RF $=0$ were considered immune (I), those with $R F<1$ as resistant $(R)$, and susceptible (S) those with RF> 1, according to Oostenbrink (1966). The number of eggs per gram of root (NERG) was also calculated.

The data were subjected to analysis of variance and means grouping by the Scott-Knott test, using the Genes statistical program (CRUZ, 2013).

\section{Results and Discussion}

There were significant differences for all characters in the different periods of evaluation according to the analysis of variance $(P<0.05)$. The environmental variation coefficients were higher for the number of eggs per gram of root (NERG), indicating lower experimental precision for this character. However, the values above the unit for the ratio between the coefficient of genotypic and environmental variation $(\mathrm{CVg} / \mathrm{CV})$, indicate a good experimental precision or the predominance of genetic variation over the environment for the most characters, which can proportionate reliability in the estimates and conclusions based on these results (Tables 1, 2 and 3).

For 2013, it was found that, although there were significant differences among genotypes for all traits, the evaluated genotypes were considered susceptible to $M$. enterolobii; and even those with 
lower values of the reproduction factor (FR), did not differ statistically from the susceptible tomato 'Rutgers', including the interspecific hybrid with $S$. stramonifolium. The tomato cultivar 'Nemadoro', a pattern of resistance to root-knot nematodes in this study, behaved as resistant to this species of nematode (Table 1).

Table 1. The reaction of eggplant accessions, and interspecific hybrids to Meloidogyne enterolobii. Embrapa Hortaliças, 2013.

\begin{tabular}{lcccc}
\hline & \multicolumn{4}{l}{ Meloidogyne enterolobii } \\
\cline { 2 - 5 } Accessions & EMI & Gl & NERG & RF/Reaction \\
\hline CNPH 005 & $5.00 \mathrm{a}$ & $5.00 \mathrm{a}$ & $3593.33 \mathrm{a}$ & $8.53 \mathrm{c} / \mathrm{S}$ \\
CNPH 007 & $4.67 \mathrm{~b}$ & $4.50 \mathrm{~b}$ & $4430.62 \mathrm{a}$ & $11.43 \mathrm{c} / \mathrm{S}$ \\
CNPH 008 & $4.50 \mathrm{~b}$ & $4.33 \mathrm{~b}$ & $8767.38 \mathrm{a}$ & $15.90 \mathrm{~b} / \mathrm{S}$ \\
CNPH 012 & $5.00 \mathrm{a}$ & $4.83 \mathrm{a}$ & $5538.27 \mathrm{a}$ & $10.38 \mathrm{c} / \mathrm{S}$ \\
CNPH 014 & $5.00 \mathrm{a}$ & $4.83 \mathrm{a}$ & $5864.43 \mathrm{a}$ & $13.97 \mathrm{~b} / \mathrm{S}$ \\
CNPH 016 & $4.17 \mathrm{~b}$ & $4.17 \mathrm{~b}$ & $4641.10 \mathrm{a}$ & $15.92 \mathrm{~b} / \mathrm{S}$ \\
CNPH 017 & $4.33 \mathrm{~b}$ & $4.00 \mathrm{~b}$ & $6372.75 \mathrm{a}$ & $11.63 \mathrm{c} / \mathrm{S}$ \\
CNPH 171 & $4.83 \mathrm{a}$ & $4.67 \mathrm{a}$ & $3642.98 \mathrm{a}$ & $9.10 \mathrm{c} / \mathrm{S}$ \\
CNPH 778 & $5.00 \mathrm{a}$ & $5.00 \mathrm{a}$ & $5610.72 \mathrm{a}$ & $22.57 \mathrm{a} / \mathrm{S}$ \\
CNPH 435 & $4.83 \mathrm{a}$ & $4.83 \mathrm{a}$ & $5779.95 \mathrm{a}$ & $23.40 \mathrm{a} / \mathrm{S}$ \\
Eggplant Ciça & & & & $11.52 \mathrm{c} / \mathrm{S}$ \\
Solanum gilo & $5.00 \mathrm{a}$ & $4.50 \mathrm{~b}$ & $1812.87 \mathrm{~b}$ & \\
S. stramonifolium & & & & $7.85 \mathrm{c} / \mathrm{S}$ \\
Eggplant Ciça & $5.00 \mathrm{a}$ & $5.00 \mathrm{a}$ & $1181.82 \mathrm{~b}$ & $8.20 \mathrm{c} / \mathrm{S}$ \\
\hline Rutgers & $4.67 \mathrm{~b}$ & $4.50 \mathrm{~b}$ & $4466.88 \mathrm{a}$ & $0.03 \mathrm{~d} / \mathrm{R}$ \\
\hline Nemadoro & $1.50 \mathrm{c}$ & $1.17 \mathrm{c}$ & $119.83 \mathrm{~b}$ & 12.17 \\
\hline General mean & 4.54 & 4.38 & 4415.92 & 22.3 \\
CV & 5.33 & 6.49 & 28.25 & 1.25 \\
CVg/CV & 2.04 & 1.88 & 1.14 & 0.01 \\
P statistic & 0.00 & 0.00 & 0.00 & 14 \\
\hline
\end{tabular}

EMI and GI: egg mass and of galls indexes); NERG: number of eggs per root gram; RF: reproduction factor; Reaction: reaction of resistance: $I=I m m u n e ; R=R e s i s t a n t$ and $S=S$ Susceptible. Means followed by the same letter on the column did not differ by the Scott-Knott test $(p<0.05)$. CV: coefficient of environmental variation in percentage, CVg/CV: ratio genotypic and environmental variation. $\mathrm{P}$ statistic: $\mathrm{P}$ statistic of the variance analysis.

As for 2017, although all accessions were also classified as susceptible to $M$. incognita according to the reaction pattern, that is, the final nematode population was greater than the initial one. The resistance pattern $S$. stramonifolium var. inerme, the interspecific hybrid with $S$. scuticum, in addition to the BER 3150 access, had significantly lower RF compared to other genotypes, which did not differ from the susceptibility pattern, the tomato cultivar 'Rutgers'. While for M. enterolobii, all genotypes were susceptible, except the resistance pattern S. stramonifolium var. inerme, which had an RF lower than the unit (Table 2). 
Table 2. The reaction of eggplant accessions, and an interspecific hybrid to Meloidogyne incognita and $M$. enterolobii. Embrapa Hortaliças, 2017.

\begin{tabular}{lcccc}
\hline & \multicolumn{4}{c}{ Meloidogyne incognita } \\
\cline { 2 - 5 } Accessions & EMI & GI & NERG & RF/Reaction \\
\hline BER 3150 & $4.67 \mathrm{a}$ & $5.00 \mathrm{a}$ & $5319.17 \mathrm{a}$ & $11.50 \mathrm{~b} / \mathrm{S}$ \\
BER 171 x BER EG203 & $4.67 \mathrm{a}$ & $5.00 \mathrm{a}$ & $4201.00 \mathrm{~b}$ & $30.62 \mathrm{a} / \mathrm{S}$ \\
BER 778 x BER EG203 & $4.17 \mathrm{~b}$ & $5.00 \mathrm{a}$ & $3546.17 \mathrm{~b}$ & $25.87 \mathrm{a} / \mathrm{S}$ \\
BER EG203 x S. scuticum & $4.17 \mathrm{~b}$ & $3.83 \mathrm{~b}$ & $1398.83 \mathrm{c}$ & $7.65 \mathrm{~b} / \mathrm{S}$ \\
\hline S. stramonifolium var. & & & & \\
inerme & $4.33 \mathrm{~b}$ & $4.00 \mathrm{~b}$ & $1339.00 \mathrm{c}$ & $5.03 \mathrm{~b} / \mathrm{S}$ \\
Rutgers & $5.00 \mathrm{a}$ & $5.00 \mathrm{a}$ & $6223.50 \mathrm{a}$ & $34.70 \mathrm{a} / \mathrm{S}$ \\
\hline General mean & 4.50 & 4.64 & 3671.28 & 19.23 \\
CV & 4.45 & 4.28 & 20.88 & 22.06 \\
CVg/CV & 0.65 & 1.30 & 1.43 & 1.67 \\
P statistic & 0.01 & 0.00 & 0.00 & 0.01 \\
\hline & \multicolumn{5}{c}{ Meloidogyne enterolobii } \\
Accessions & EMI & GI & NERG & RF/Reaction \\
\hline BER 3150 & $4.00 \mathrm{~b}$ & $4.17 \mathrm{~b}$ & $6208.33 \mathrm{a}$ & $21.47 \mathrm{a} / \mathrm{S}$ \\
BER 171 x BER EG203 & $4.17 \mathrm{~b}$ & $4.83 \mathrm{a}$ & $2581.50 \mathrm{a}$ & $19.00 \mathrm{a} / \mathrm{S}$ \\
BER 778 x BER EG203 & $4.00 \mathrm{~b}$ & $3.67 \mathrm{c}$ & $5086.33 \mathrm{a}$ & $29.07 \mathrm{a} / \mathrm{S}$ \\
BER EG203 x S. scuticum & $4.00 \mathrm{~b}$ & $4.17 \mathrm{~b}$ & $9272.67 \mathrm{a}$ & $26.83 \mathrm{a} / \mathrm{S}$ \\
\hline S. stramonifolium var. & & & & \\
inerme & $3.40 \mathrm{c}$ & $3.40 \mathrm{c}$ & $1073.39 \mathrm{a}$ & $0.86 \mathrm{~b} / \mathrm{R}$ \\
Rutgers & $5.00 \mathrm{a}$ & $4.83 \mathrm{a}$ & $6529.67 \mathrm{a}$ & $32.68 \mathrm{a} / \mathrm{S}$ \\
\hline General mean & 4.09 & 4.18 & 5125.31 & 21.65 \\
CV & 4.00 & 5.54 & 37.31 & 25.32 \\
CVg/CV & 1.37 & 1.09 & 0.75 & 1.43 \\
P statistic & 0.00 & 0.01 & 0.55 & 0.00 \\
\hline
\end{tabular}

EMI and GI: egg mass and of galls indexes; NERG: number of eggs per root gram; RF: reproduction factor; Reaction: reaction of resistance: I=Immune; $R=$ Resistant and $S=S$ Susceptible. Means followed by the same letter on the column did not differ by the Scott-Knott test $(p<0.05)$. CV: coefficient of environmental variation in percentage, $\mathrm{CVg} / \mathrm{CV}$ : ratio genotypic and environmental variation. P statistic: $P$ statistic of the variance analysis.

Regarding eggplant reaction to these nematode species, some studies have proven the existence of resistance to $M$. javanica and $M$. incognita, but there are no evaluation reports for M. enterolobii. Boiteux and Charchar (1996) evaluated 39 accessions of eggplant and one access of $S$. turvum for the reaction to $M$. javanica and found that in addition to the access of $S$. torvum (CNPH 610), one access of eggplant with code A-264-A presented a value of zero for the NERG, and concluded that this access presents the potential for crossbreeding aiming at resistance to this species of nematodes. Likewise, Tanimola et al. (2015), evaluated the reaction of 7 eggplant accessions to $M$. incognita and found that two, Ngwa large and Anara ogi, were resistant, with RF lower than the unit. As well, Colak-Ates et al. (2018) evaluated 77 eggplant genotypes and found the P29 and P52 acessions as potential resistant sources to $M$. incognita.
However, most studies indicate that, in general, accesses or genotypes are classified as susceptible, showing different degrees of susceptibility; corroborating with the present work results. Some examples are the works of Ullah et al. (2011), that evaluated the reaction of six eggplant cultivars to $M$. incognita, and Shakeel et al. (2012) that evaluated 10 cultivars also for $M$. incognita, all classified as susceptible. Equivalent results were obtained by Begum et al. (2014), which evaluated 13 eggplant cultivars to root-knot nematodes; Abdulsalam et al. (2018) that evaluated three eggplant cultivars reaction to $M$. incognita and Ozarslandan et al. (2019), that evaluated five aggplant accessions for the same nematode specie.

The accessions of scarlet eggplant (Table 3), genotypes CNPH 056, CNPH 070, CNPH 220 and $\mathrm{CNPH} 363$, regarding their gall index (GI) and egg mass index (EMI) values, presented a better 
response to $M$. incognita and $M$. javanica than the susceptibility pattern, tomato cultivar 'Rutgers'; however, they were more susceptible compared to the resistance pattern, tomato cultivar 'Nemadoro'. A similar result was obtained for the accesses CNPH 026, CNPH 051, CNPH 219, specifically for $M$. incognita, and for the accesses CNPH 027 and CNPH 223 for M. javanica. Concerning $M$. enterolobii, the accessions CNPH
070, CNPH 219 and CNPH 387, presented a better or equivalent resistance reaction than the tomato cultivar 'Nemadoro', as to GI and EMI values, and considering that this was the most aggressive nematode species, with the highest overall average value for these characters.

Table 3. The reaction of gilo accessions to Meloidogyne incognita, M. javanica, and M. enterolobii. Embrapa Hortaliças, 2016.

\begin{tabular}{|c|c|c|c|c|c|c|}
\hline \multirow[t]{2}{*}{ Accessions } & \multicolumn{2}{|c|}{ M. incognita } & \multicolumn{2}{|c|}{ M. javanica } & \multicolumn{2}{|c|}{ M. enterolobii } \\
\hline & GI & EMI & GI & EMI & GI & EMI \\
\hline CNPH 024 & $5.00 \mathrm{a}$ & $3.00 \mathrm{~b}$ & $5.00 \mathrm{a}$ & $4.50 \mathrm{a}$ & $5.00 \mathrm{a}$ & $3.67 a$ \\
\hline CNPH 026 & $3.50 \mathrm{c}$ & $3.50 \mathrm{~b}$ & $4.67 \mathrm{a}$ & $4.33 \mathrm{a}$ & $5.00 \mathrm{a}$ & $4.50 \mathrm{a}$ \\
\hline CNPH 027 & $4.83 \mathrm{a}$ & $4.00 \mathrm{a}$ & $3.33 c$ & $3.17 c$ & $5.00 \mathrm{a}$ & $3.50 \mathrm{~b}$ \\
\hline CNPH 037 & $4.17 b$ & $4.00 \mathrm{a}$ & $5.00 \mathrm{a}$ & $4.17 \mathrm{a}$ & $4.67 \mathrm{a}$ & $3.00 \mathrm{~b}$ \\
\hline CNPH 042 & $4.17 \mathrm{~b}$ & $4.17 \mathrm{a}$ & $5.00 \mathrm{a}$ & $3.67 \mathrm{~b}$ & $5.00 \mathrm{a}$ & $5.00 \mathrm{a}$ \\
\hline CNPH 051 & $3.67 c$ & $2.67 \mathrm{~b}$ & $5.00 \mathrm{a}$ & $4.33 \mathrm{a}$ & $5.00 \mathrm{a}$ & $4.17 \mathrm{a}$ \\
\hline CNPH 053 & $5.00 \mathrm{a}$ & $3.83 \mathrm{a}$ & $5.00 \mathrm{a}$ & $4.33 \mathrm{a}$ & $4.33 \mathrm{~b}$ & $3.83 \mathrm{a}$ \\
\hline CNPH 056 & $3.17 \mathrm{c}$ & $3.00 \mathrm{~b}$ & $2.67 \mathrm{~d}$ & $2.67 c$ & $5.00 \mathrm{a}$ & $4.00 \mathrm{a}$ \\
\hline CNPH 065 & $5.00 \mathrm{a}$ & $4.50 \mathrm{a}$ & $5.00 \mathrm{a}$ & $4.33 \mathrm{a}$ & $4.17 \mathrm{~b}$ & $4.17 \mathrm{a}$ \\
\hline CNPH 070 & $4.50 \mathrm{~b}$ & $3.17 b$ & $3.33 \mathrm{c}$ & $2.33 \mathrm{c}$ & $3.50 \mathrm{c}$ & $3.17 b$ \\
\hline CNPH 206 & $4.33 \mathrm{~b}$ & $3.67 a$ & $5.00 \mathrm{a}$ & $3.83 \mathrm{~b}$ & $5.00 \mathrm{a}$ & $3.83 \mathrm{a}$ \\
\hline CNPH 218 & $5.00 \mathrm{a}$ & $3.50 \mathrm{~b}$ & $5.00 \mathrm{a}$ & $4.17 \mathrm{a}$ & $5.00 \mathrm{a}$ & $4.00 \mathrm{a}$ \\
\hline CNPH 219 & $3.50 \mathrm{c}$ & $3.17 b$ & $5.00 \mathrm{a}$ & $3.50 \mathrm{~b}$ & $4.17 \mathrm{~b}$ & $3.50 \mathrm{~b}$ \\
\hline CNPH 220 & $4.50 \mathrm{~b}$ & $3.00 \mathrm{~b}$ & $3.33 \mathrm{c}$ & $3.67 \mathrm{~b}$ & $5.00 \mathrm{a}$ & $3.00 \mathrm{~b}$ \\
\hline CNPH 221 & $5.00 \mathrm{a}$ & $3.83 \mathrm{a}$ & $5.00 \mathrm{a}$ & $3.00 \mathrm{c}$ & $5.00 \mathrm{a}$ & $2.67 \mathrm{~b}$ \\
\hline CNPH 222 & $5.00 \mathrm{a}$ & $3.50 \mathrm{~b}$ & $5.00 \mathrm{a}$ & $4.33 \mathrm{a}$ & $5.00 \mathrm{a}$ & $3.67 \mathrm{a}$ \\
\hline CNPH 223 & $5.00 \mathrm{a}$ & $3.00 \mathrm{~b}$ & $3.67 c$ & $3.50 \mathrm{~b}$ & $4.83 \mathrm{a}$ & $3.17 b$ \\
\hline CNPH 363 & $4.67 \mathrm{~b}$ & $3.00 \mathrm{~b}$ & $4.00 \mathrm{~b}$ & $3.00 \mathrm{c}$ & $5.00 \mathrm{a}$ & $3.83 a$ \\
\hline CNPH 387 & $5.00 \mathrm{a}$ & $3.33 \mathrm{~b}$ & $5.00 \mathrm{a}$ & $4.17 \mathrm{a}$ & $4.00 \mathrm{~b}$ & $3.50 \mathrm{~b}$ \\
\hline CNPH 435 & $5.00 \mathrm{a}$ & $3.50 \mathrm{~b}$ & $5.00 \mathrm{a}$ & $3.83 \mathrm{~b}$ & $4.67 \mathrm{a}$ & $4.00 \mathrm{a}$ \\
\hline Nemadoro & $1.00 \mathrm{~d}$ & $1.00 \mathrm{c}$ & $1.00 \mathrm{e}$ & $1.00 \mathrm{~d}$ & $5.00 \mathrm{a}$ & $3.00 \mathrm{~b}$ \\
\hline Rutgers & $5.00 \mathrm{a}$ & $4.17 \mathrm{a}$ & $5.00 \mathrm{a}$ & $4.67 \mathrm{a}$ & $5.00 \mathrm{a}$ & $4.17 \mathrm{a}$ \\
\hline General means & 4.36 & 3.39 & 4.36 & 3.66 & 4.74 & 3.70 \\
\hline CV (\%) & 6.05 & 8.53 & 5.54 & 8.14 & 4.82 & 9.13 \\
\hline $\mathrm{CVg} / \mathrm{CV}$ & 1.91 & 1.15 & 2.31 & 1.40 & 0.83 & 0.62 \\
\hline P statistic & 0.00 & 0.00 & 0.00 & 0.00 & 0.00 & 0.01 \\
\hline
\end{tabular}

$\mathrm{EMI}$ and GI: egg mass and of galls indexes; NERG: number of eggs per root gram; RF: reproduction factor; Reaction:: I=Immune; R=Resistant and S=Susceptible. Means followed by the same letter on the column did not differ by the ScottKnott test $(p<0.05)$. CV: coefficient of environmental variation in percentage, $\mathrm{CVg} / \mathrm{CV}$ : rate among the genotypic and environmental variation. P statistic: P statistic of the variance analysis.

For scarlet eggplant, studies on nematode resistance are scarce, but it is known that this species is very susceptible to root-knot nematodes (PINHEIRO et al., 2013). Looking for sources of resistance to $M$. javanica and $M$. incognita, Tzortzakakis et al. (2006), evaluated 7 accessions of scarlett eggplant and verified the presence of galls and egg masses in all the genotypes. The same was found by Ozarslandan et al. (2019), that evaluated five accessions that were susceptible to $M$. incognita.

Since resistant eggplant and scarlet eggplant genotypes to root-knot nematodes are difficult to obtain by conventional breeding, and 
crossing these with wild Solanaceae species with a higher degree of resistance to nematodes, such as S. stramonifolium (PINHEIRO et al., 2014b; PEREIRA et al., 2018) and S. scuticum (PINHEIRO et al., 2014a), is feasible, a possible strategy that could be employed would be developing hybrid rootstocks, which are compatible to vegetable Solanaceae, species, maintaining the parent's resistance, and having complementary traits such a lower amount of thorns (MENDONÇA et al., 2017).

In the present study, regarding the interspecific hybrids resistance to nematodes, this strategy has shown promise in the case of the BER EG203 x S. scuticum since their hybrid presented an RF for $M$. incognita similar to the $S$. stramonifolium var. inerme (Table 2). On the other hand, it was not effective for M. enterolobii (Tables 1 and 2), probably because this species of nematodes are more aggressive to Solanaceae than the others evaluated (KIEWNICK et al., 2009; MELO et al., 2011).

Gisbert et al. (2012) evaluated the response of the hybrid rootstocks between eggplant $\mathrm{x}$ scarlet eggplant and eggplant $\times S$. incanum, compared to the respective parents, in a field naturally infested with $M$. incognita, and found the eggplant parents were more resistant, and that both progenies showed intermediate resistance reaction, therefore, although there was compatibility of grafting, this strategy was not efficient for the nematode control.

\section{Conclusions}

All the eggplant accessions evaluated in this study were susceptible to $M$. incognita and $M$. enterolobii, however, the accession BER 3150 presents a lower degree of susceptibility to $M$. incognita.

Scarlett eggplant genotypes CNPH 056, CNPH 070, CNPH 220, and CNPH 363 has a better response to $M$. incognita and $M$. javanica than the susceptibility pattern, tomato cultivar 'Rutgers', but more susceptible than the pattern of resistance, tomato cultivar 'Nemadoro'.

The scarlet eggplant genotypes CNPH 070, CNPH 219 and CNPH 387, are better or equivalente in resistance to $M$. enterolobii compared to the tomato cultivar 'Nemadoro'.

The interspecific hybrid BER EG203 x $S$. scuticum can be recommended as a rootstock for eggplant cultivars susceptible to $M$. incognita; as well the wild Solanaceae S. stramonifolium var. inerme can also be indicated as a rootstock, mainly for areas where $M$. enterolobii occurs.

\section{References}

ABDULSALAM, S.; CHINDO, P.; AGBENIN, N.; ONU, I. Reaction of eggplant (Solanum melongena L.) varieties and roma vf tomato to root-knot nematodes (Meloidogyne incognita) in Samaru Zaria. Fudma Jaat, v.4, p.122-130, 2018.

BEGUM, K.; HASAN, N.; KHANDKER, S.; AMINUZZAMAN, F. M.; ASADUZZAMAN, M.; AKHTAR, N. Evaluation of Brinjal Cultivars (Solanum Melongena) Against Root-Knot Nematode Meloidogyne spp. Applied Science Reports, v.7, p.129-134, 2014. http://dx.doi.org/10.15192/PSCP.ASR.2014.3.3.1 $\underline{29134}$

BERNARD, G. C.; EGNIN, M.; BONSI, C. The Impact of Plant-Parasitic Nematodes on Agriculture and Methods of Control. In: Nematology: concepts, diagnosis and control. (Eds). SHAH, M. M.; MAHAMOOD, M. 2017. p.121-151. https://doi.org/10.5772/intechopen.68958

BONETI, J. I. S.; FERRAZ, S. Modificação do método de Hussey e Barker para extração de ovos de Meloidogyne exigua de raízes de cafeeiro. Fitopatologia Brasileira, v. 6, p. 553, 1981.

BOITEUX, L. S.; CHARCHAR, J. M. Genetic resistance to root-knot nematode (Meloidogyne javanica) in eggplant (Solanum melongena). Plant breeding, v.115, p.198-200, 1996.

https://doi.org/10.1111/j.14390523.1996.tb00902.x

COHEN, R.; DOMBROVSKY, A.; LOUWS, F. J. Grafting as agrotechnology for reducing disease damage. In: Vegetable grafting: principles and practices. (Eds.). COLLA, G.; PÉREZ-ALFOCEA, F.; SCHWARZ, D. Oxfordshire, UK: CABInternational, 2017. p.55-170. https://doi.org/10.1079/9781780648972.0155

COLAK-ATES, A.; FIDAN, H.; OZARSLANDAN, A.; ATA, A. Determination of the resistance of certain eggplant lines against fusarium wilt, potato $y$ potyvirus and root-knot nematode using molecular and classic methods. Fresenius Environmental Bulletin, v.27, p.7446-7453, 2018.

CRUZ, C. D. Genes: a software package for analysis in experimental statistics and quantitative genetics. Acta Scientiarum 
Agronomy, v.35, p.271-276, 2013. https://doi.org/10.4025/actasciagron.v35i3.212 $\underline{51}$

DICKSON, D. W.; STRUBLE, F. B. A sieving-staining technique for extraction of egg mass of Meloidogyne incognita from soil. Phytopathology, v.55, p.497, 1965.

GISBERT, C.; PROHENS, J.; NUEZ, F. Performance of eggplant grafted onto cultivated, wild, and hybrid materials of eggplant and tomato. International Journal of Plant Production, v.5, p.367-380, 2012. https://www.sid.ir/en/Journal/ViewPaper.aspx?! $\mathrm{D}=213922$

GOTO, R.; SANTOS, H. S.; CAÑIZARES, K. A. L. (Org.). Enxertia em hortaliças. Botucatu: UNESP, 2003. 86p.

MANGAN, F. X.; MENDONÇA, R. U.; MOREIRA, M.; NUNES, S. V.; FINGERN F. L.; BARROS, Z. J.; GALVÃO, H.; ALMEIDA, G. C.; SILVA, R. A. N.; ANDERSON, M. D. Production and marketing of vegetables for the markets in the United States. Horticultura Brasileira, v.26, n.1, p.6-14, 2008. https://doi.org/10.1590/S0102-

05362008000100002

MELO, O. D.; MALUF, W. R. S.; GONÇALVES, R. J.; NETO, Á. C. G.; GOMES, L. A. A.; de CASTRO CARVALHO, R. Triagem de genótipos de hortaliças para resistência a Meloidogyne enterolobii. Pesquisa Agropecuária Brasileira, v.46, p.829-835, 2011. http://dx.doi.org/10.1590/S0100204X2011000800007

MENDONÇA, J. L.; LOPES, C. A.; MOITA, A. W. Compatibilidade de enxertia de híbridos interespecíficos de Solanum com tomateiro visando controle de patógenos de solo. Savannah Journal of Research and Development, v.1, p.3438, 2017. https://doi.org/10.26512/savannahjournal.v1i1.7 $\underline{366}$

MONTEIRO, A . B. Obtenção de híbridos e análise da heterose em jiló (Solanum gilo Raddi). Lavras: UFLA, 2009. 46 p. Dissertação de mestrado - Pós graduação em Fitotecnia.

NTALLI, N.; RATAJCZAK, M.; OPLOS, C.; MENKISSOGLU-SPIROUDI, U.; ADAMSKI, Z. Acetic acid, 2-undecanone, and (e)-2-decenal ultrastructural malformations on Meloidogyne incognita. Journal of nematology, v.48, p.248260, 2016. https://doi.org/10.21307/jofnem2017-033

OOSTENBRINK, M. Major characteristics of the relation between nematodes and plants. Mededelingen Landbouw, v.66, p.1-46, 1966.

OZARSLANDAN, A.; ATA, A.; KELES, D. Investigation of resistant of eggplant genotypes against root knot nematode (Meloidogyne incognita (kofoid \& white, 1919) chitwood, 1949). Feb-fresenius environmental bulletin, p.48114815, 2019.

PEREIRA, R. B.; PINHEIRO, J. B.; TORRES, T. B.; MENDONÇA, J. L.; LUCAS, G. C.; GUIMARÃES, J. A. Potential of wild Solanum stramonifolium accesses as rootstock resistant to soilborne pathogens in tomato crops. Horticultura Brasileira, v.36, p.235-239, 2018. https://doi.org/10.1590/s0102-053620180215

PINHEIRO, J. B.; PEREIRA, J. D. S.; SANTANA, J. P. Solanáceas silvestres: potencial de uso como porta-enxertos resistentes ao nematóide-dasgalhas (Meloidogyne ssp.). Brasília: Embrapa Hortaliças, 2009. 19p. (Boletim de Pesquisa e Desenvolvimento).

PINHEIRO, J. B.; PEREIRA, R. B.; de CARVALHO, A. D. F.; AGUIAR, F. M. Ocorrência de nematoide na cultura do jiló e berinjela. Brasília: Embrapa Hortaliças, 2013. 8p. (Circular Técnica; 125).

PINHEIRO, J.; MENDONCA, J. L.; RODRIGUES, C. D. S.; PEREIRA, R.; SUINAGA, F. Reação de Solanum scuticum a $M$. enterolobii. Brasília: Embrapa Hortaliças, 2014a, 24p. (Boletim de Pesquisa e Desenvolvimento; 106)

PINHEIRO, J. B.; MENDONÇA, J. L.; RODRIGUES, C. S.; PEREIRA, R. B.; SUINAGA, F. A. Avaliação de Solanum stramonifolium para reação a Meloidogyne enterolobii. Brasília: Embrapa Hortaliças, 2014b. 16p. (Boletim de Pesquisa e Desenvolvimento; 124)

PINHEIRO, J. B.; PEREIRA, R. B.; FREITAS, R. A.; MELO, R. A. C. E. A cultura do jiló. Brasília: Embrapa, 2015. 70 p. (Coleção Plantar; 75). 
PINHEIRO, J. B.; SILVA, G. O.; MACEDO, A. G.; BISCAIA, D.; MELO, R. D. C. Evaluation of sources of resistance to Meloidogyne enterolobii in Solanum stramonifolium and S. scuticum as potential rootstocks for cultivated solanaceae. Nematropica, v. 50, p. 144-150, 2020.

RAMADAN, W. A.; SOLIMAN, G. M. Effect of different applications of bio-agent Achromobacter xylosoxidans against Meloidogyne incognita and Gene Expression in Infected Eggplant. Jordan Journal of Biological Sciences, v. 13, p. 363-370, 2020.

SHAKEEL, Q.; JAVED, N.; KHAN, S. A.; HAQ, I. U.; ANWAR, S. A.; KHAN, N. A.; AMRAO, L. Response of eggplant (Solanum melongena L.) cultivars to Meloidogyne incognita infection. Pakistan Journal of Nematology, v. 30, p. 169-178, 2012.

TANIMOLA, A. A.; ASIMIEA, A. O.; OFOEGBU, E. N. Evaluation of seven eggplant (Solanum species) accessions for resistance to root-knot nematode (Meloidogyne incognita). JNKVV Research Journal, v. 49, p. 15-21, 2015.

TAYLOR, A. L.; SASSER, J. N. Biology, identification and control of root-knot nematodes (Meloidogyne species). Raleigh: North Carolina State University Graphics, 1978. $111 p$.

TZORTZAKAKIS, E. A.; BLETSOS, F. A.; AVGELIS, A. D. Evaluation of Solanum rootstock accessions for control of root-knot nematodes and tobamoviruses. Journal of Plant Diseases and Protection, v.113, p.188-189, 2006. https://doi.org/10.1007/BF03356178

ULLAH, Z.; ANWAR, S. A.; JAVED, N.; KHAN, S. A.; SHAHID, M. Response of six eggplant cultivars to Meloidogyne Incognita. Pakistan Journal of Phytopathology, v.23, p.152-155, 2011. 